\title{
KEPEMIMPINAN SPIRITUAL (SPIRITUAL LEADERSHIP) GURU SEKOLAH DASAR DALAM PEMBENTUKAN KARAKTER PESERTA DIDIK
}

\author{
Siti Maulidatul Mukaromah \\ Program Magister Studi PGMI UIN Sunan Kalijaga Yogyakarta \\ Jl. MarsdaAdi Sucipto Yogyakarta \\ e-mail:maulidalbr@gmail.com
}

\begin{abstract}
This article discusses the model of spiritual leadership of elementary school teachers in the character formation of students, which teacher leadership in the classroom influences whether or not the character possessed by the students. The research method used library reserarch. Library research is a research conducted by researchers by collecting a number of books, magazines, leaflets pertaining with problems and research objectives. The findings in the research of spiritual leadership applied by elementary school teachers in leading the students, teachers always lead by using heart with the charactheristic are taqwa, tawakal and tawadhu (3T). So, the studentswill have a good character.
\end{abstract}

Keywords: teachers, spiritual leadership, character building

\begin{abstract}
Abstrak
Artikel ini membahas tentang model kepemimpinan spiritual (spiritual leadership) guru sekolah dasar dalam pembentukan karakter peserta didik, yang mana kepemimpinan guru di kelas berpengaruh pada baik buruknya karakter yang dimiliki peserta didik. Metode penelitian yang digunakan dalam penulisan studi ini adalah studi pustaka (library reserarch). Studi pustaka (library research) merupakan penelitian yang dilakukan oleh peneliti dengan mengumpulkan sejumlah buku-buku, majalah, leaflet yang berkenaan dengan masalah dan tujuan penelitian. Temuan dalam penelitian yaitu kepemimpinan spiritual yang di terapkan oleh guru sekolah dasar dalam memimpin peserta didiknya senantiasa memimpin dengan menggunakan hati yang memiliki karaketristik yaitu Taqwa, Tawakal, dan Tawadhu (3T). Sehingga akan menghasilkan peserta didik yang berkarakter.
\end{abstract}

Kata kunci: guru, kepemimpinaan spiritual, pembentukan karakter

\section{Pendahuluan}

Tujuan pendidikan yang berkualitas disekolah tidak terlepas dari kerjasama seluruh komponen sumber daya, khususnya Sumber Daya Manusia (SDM) disekolah tersebut. SDM guru merupakan proporsi terbesar dari tenaga pendidikan lain yang bertanggung jawab dalam meningkatkan kualitas pendidikan suatu sekolah, karena di pundaknyalah melekat tugas mulia yakni menciptakan generasi yang paripurna. Menciptakan generasi yang paripurna bukanlah tugas yang mudah seperti membalikan telapak tangan, melainkan tugas 
yang selalu berproses tanpa henti. Apalagi, masih banyak terdapat problematika pendidikan yang masih menjadi pekerjaan rumah bersam ${ }^{1}$. Hal ini merupakan tantangan bagi guru, karena ditangannyalah tercipta perubahan.

Hal tersebut senada dengan UU No. 20 tahun 2003 tentang sistem pendidikan nasional yang terdapat pada pasal $3 \mathrm{UU}$ yaitu“ pendidikan nasional berfungsi mengembangkan kemampuan dan membentuk karakter serta peradaban bangsa yang bermartabat guna mencerdaskan kehidupan bangsa. ${ }^{2}$ UU tersebut dengan tegas menjelaskan bahwa pendidikan itu untuk membentuk karakter bangsa, sehingga hal yang terpenting dalam pendidikan adalah karakter peserta didik, karena dengan memiliki karakter yang baik peserta didik akan mampu menghadapi perkembangan zaman dengan segala kompleksitasny.

Upaya untuk mensinergiskan hal tersebut diperlukan sumber daya yang berkualitas, guru tidak hanya berperan untuk mengajarkan materi melainkan peran guru lebih dari itu, yaitu yang terpenting adalah membentuk karakter peserta didik yang mana membutuhkan proses tanpa berkesudahan, itulah tugas seorang guru yang terkadang membuat frustasi ketika mengalami kegagalan, tetapi tugas tersebut juga yang menjadikan guru itu mulia dengan keberhasilannya membentuk karakter peserta didik.

Keberhasilan seorang guru dalam pembentukan karakter peserta didik tidak terlepas dari perannya sebagai pemimpin ${ }^{3}$ untuk peserta didik dikelasnya. Guru

1 Nurul Afifah, "Problematika Pendidikan di Indonesia (Telaah Aspek Pembelajaran)," Elementary: Jurnal Ilmiah Pendidikan Dasar 1, no. 1 (2015): 41.

2 Lihat UU RI No. 20 Tahun 2003 tentang Sistem Pendidikan Nasional.

3 Syaiful Bahri Djamarah, Guru dan Anak Didik dalam Interaksi Edukatif (Suatu Pendekatan Teoretis Psikologis) (Jakarta: Rineka Cipta, 2005), 39. sebagai pemimpin akan memberikan pengaruh besar terhadap yang dipimpinnya. Kepemimpinan guru merupakan salah satu faktor yang mempengaruhi pembentukan karakter peserta didik ${ }^{4}$, mengingat dalam filosofi jawa guru merupakan orang yang digugu lan ditiru serta merupakan ujung tombak dikelas yang berhadapan langsung dengan peserta didik. ${ }^{5}$ Guru mendampingi peserta didik sehingga Ia akan menjadi pemimpin berikutnya. $^{6}$ enada dengan salah satu teori kepemimpinan yakni teori sifat yang mana teori tersebut menjelaskan bahwa keberhasilan seorang pemimpin ditentukan oleh sifat kepribadian baik secara fisik maupun psikologis. ${ }^{7}$ Sifat kepribadian begitu erat kaitannya dengan karakter dan karakter tak lepas dari nilai spiritual.

Beberapa penelitian yang dikutip oleh Tobroni dalam "The Spiritual Leadership (Pengektifan Organisasi Noble Industry melalui Prinsip-prinsip Spiritual Etis)" menunjukkan signifikansi antara kepemimpinan yang efektif dengan organisasi yang efektif. penelitian Edmonds mengemukakan, organisasi-organisasi yang dinamis yang senantiasa berupaya meningkatkan prestasi kerjanya dipimpin oleh pemimpin yang baik. Penelitian Hallinger dan Lithwood menyimpulkan bahwa organisasi sekolah yang efektif senantiasa dipimpinolehmanajer yang efektif pula. Kedua penelitian tersebut berasumsibahwapemimpinmerupakanagen perubahan yang terpenting. Kepemimpinan yang kuat mampu memerankan diri dalam

4 Doni Koesoema A, Pendidikan Karakter (Utuh dan Menyeluruh) (Yogyakarta: Kanisius, 2012), 82.

5 Syamsul Kurniawan, Pendidikan Karakter (Konsepsi \& Implementasinya Secara Terpadu di Lingkungan Keluarga, Sekolah, Perguruan Tinggi dan Masyarakat) (Yogyakarta: Ar-Ruzz Media, 2016), 33.

6 Imas S. Wardani, "Guru sebagai Pemimpin Pendidikan," Jurnal Buana Pendidikan 10, no. 18 (2014): 27.

7 Rahmad Maulana, "Hubungan Kompetensi Sosial dengan Kinerja Guru SD Islam Bunga Bangsa Samarinda Ditinjau dari Tipe Kepribadian," Jurnal Psikologi 2, no. 2 (2014): 137-49. 
delapan peran antara lain: organisator, pengakrobat berdasarkan nilai, penolong sejati, perantara, humanis, katalis, rasionalis dan politikus. ${ }^{8}$

Efektifitas kepemimpinan sebuah organisasi tidak terlepas dari nilai-nilai spiritual. ${ }^{9}$ Oleh karena itu, merupakan sebuah hal penting untuk menanamkan nilai spiritual pada guru sebagai pemimpin dikelas. Terpenuhinya kebutuhan spiritual dikelas akan berpengaruh positif pada pembentukan karakter peserta didik serta dapat dijadikan pondasi dalam penerapan spiritual leadership.

Penelitian yang dilakukan oleh Ardha Harya Kusuma mengenai "Pengaruh Kepemimpinan GurudanDisiplinBelajarterhadap Prestasi Belajar Mata Pelajaran Ekonomi Kelas XII SMA PGRI I Pati Tahun Ajaran 2012/2013" menunjukkan bahwa kepemimpinan guru berpengaruh terhadap prestasi belajar siswa baik secara simultan maupun parsial. Hal tersebut menunjukkan bahwa pentingnya kepemimpinan guru terhadap peserta didik, yang mana konsep kepemimpinan spiritual (spiritual leadership) perlu kiranya diterapkan disekolah dasar dalam membentuk karakter peserta didik. Tujuan dari penelitian ini menemukan model kepemimpinan spiritual (spiritual leadership) bagi guru Sekolah Dasar dalam pembentukan karakter peserta didik, mengingat begitu urgent nya pendidikan dasar untuk menopang jenjang pendidikan selanjutnya.

Metode penelitian yang digunakan dalam penulisan studi ini adalah studi pustaka (library reserarch). Studi pustaka (library research) merupakan penelitian

8 Tobroni, The Spiritual Leadership (Pengefektifan Organisasi Noble Industry melalui Prinsip-prinsip Spiritual), Cet 2 (Malang: UMM Press, 2010), 4.

9 Nurfika Asmaningrum, Budi Anna Keliat, dan Sutanto Priyo Hastono, "Pengaruh Penerapan Spiritual Leadership Terhadap Komitmen Perawat Pada Organisasi Di Rumah Sakit Islam Surabaya," Jurnal Keperawatan Soedirman 6, no. 1 (Maret 2011): 11. yang dilakukan oleh peneliti dengan mengumpulkan sejumlah buku-buku, majalah, leaflet yang berkenaan dengan masalah dan tujuan penelitian.

Untuk mempertajam analisis peneliti menggunakan teknis analisis isi (content analisys), yaitu suatu analisis yang menekankan pada analisis ilmiah tentang isi pesan suatu komunikasi. ${ }^{10}$ Content analisys memanfaatkan prosedur yang dapat menarik kesimpulan shahih dari sebuah buku atau dokumen. Proses content analisys adalah dimulai dari isi pesan komunikasi tersebut, dipilah-pilah (disortir), kemudian dilakukan kategorisasi (pengelompokan) antara data yang sejenis, dan selanjutnya dianalisis secara kritis dan obyektif. Jenis data yang diperlukan dalam penelitian ini adalah data kualitatif yang sifatnya tekstual. Sumber data dipilih menjadi tiga, yaitu: sumber data primer, sekunder dan penunjang. Adapun data primer penelitian ini adalah buku-buku yang membahas tentang spiritual leadership. Dokumen sekunder dan penunjang yaitu sejumlah buku dan dokumen kepustakaan lainnya maupun hasil download di internet yang mendukung terhadap kajian kepemimpinan spiritual (spiritual leadership) dalam pembentukan karakter.

\section{Pembahasan}

\section{Guru sebagai pemimpin}

Pemimpin sekolah yang berfungsi sebagai pemimpin pengajaran merupakan keperluan mendesak untuk perkembangan pengajaran dan pembelajaran disekolah masa kini. Kepemimpinan adalah faktor yang penting dalam menentukan keberhasilan sekolah. Kepemimpinan merupakan asas paling penting dalam meningkatkan pencapaian peserta didik.Kepemimpinan dalam hal ini tidak hanya kepala sekolah dalam memimpin lembaga, melainkan peran guru sebagai pemimpin bagi peserta

${ }^{10}$ Lexy J Moleong, Metode Penelitian Kualitatif (Bandung: Remaja Rosdakarya, 1990), 163-64. 
didiknya tidak boleh diabaikan begitu saja. ${ }^{11}$ Karena guru merupakan agen perubahan dalam usaha melahirkan sekolah yang berkualitas.

Menurut Andreas Harefa tugas guru diantaramya: pembelajar belajar, pemimpin memimpin dan mendampingi pelajar agar mempersiapkan diri mereka menjadi pemimpin berikutnya. Winardi menyebutkan bahwa kepemimpinan guru mengandung makna bahwa guru bukanlah sosok yang hanya menyampaikan materi melainkan kepemimpinan guru merupakan seorang guru yang tidak mendapatkan pengangkatan formal yuridis sebagai pemimpin, memiliki sejumlah kemampuan untuk memimpin suatu kelompok dalam proses pembelajaran guna pencapaian tujuan yang telah ditetapkan. ${ }^{12}$

Muslich menyatakan bahwa kepemimpinan guru merupakan suatu kemampuan dan kesiapan yang perlu dimiliki oleh seorang guru untuk mempengaruhi, membimbing, mengarahkan dan mengelola peserta didik guna mencapai tujuan pendidikan. Sehingga keberhasilan peserta didik tidak luput dari peran penting kepemimpinan guru. ${ }^{13}$

Guru sebagai pemimpin bertugas mengelola terjadinya peristiwa belajar, yaitu guru menempatkan dirinya sebagai otoritas namun tidak berlaku otoritatif. ${ }^{14}$ Sebagaimana Ki Hajar Dewantara dalam teori kepemimpinannya yaitu Tut Wuri

11 Norashikin Abu Bakar, Ramli Basri, dan Foo Say Fooi, "Hubungan Kepimpinan Guru dengan Pencapaian Akademik Pelajar," International Journal of Education And Training 1, no. 11 (2015).

${ }^{12}$ Ardha H.Kusuma, "Pengaruh Kepemimpinan Guru dan Disiplin Belajar terhadap Prestasi Belajar Mata Pelajaran Ekonomi Siswa Kelas XI IPS SMA PGRI 1 Pati Tahun Ajaran 2012/2013" (Skripsi, Universitas Negeri Semarang, 2013), 18.

${ }^{13}$ Ibid.

14 Darwin Pangaribuan, "Peranan Seorang Guru Sebagai Pemimpin" (Seminar Pendidikan Balai Keratun, Bandar Lampung, 8 April 2010).
Handayani. Yaitu di depan menjadi teladan artinya guru sebagai pemimpin. Di tengah menjadi bagian dari peserta didik sehingga mereka sempat melihat dari dekat seluk beluk kehidupan peserta didik. Di belakang memberi dorongan bagi kemajuan belajar yang dicapai peserta didiknya.

\section{Kepemimpinan Spiritual}

Istilah "spiritual" berasal dari bahasa inggris dengan kata dasar "spirit" yang memiliki makna antara lain jiwa, roh, semangat, hantu, moral dan tujuan atau makna yang hakiki. Sedangkan dalam bahasa arab istilah spiritual terkait dengan yang ruhani dan ma'nawi dari segala sesuatu.

Makna inti dari kata spirit berikut kata jadiannya seperti spiritual dan spiritualitas adalah bermuara kepada kehakikian, keabadian dan ruh. Dalam perspektif agama, spiritualitas senantiasa berkaitan secara langsung dengan realitas tuhan. Spiritualitas bukan sesuatu yang asing bagi manusia, karena merupakan inti kemanusiaan itu sendiri. Manusia terdiri dari unsur material dan spiritual atau unsur jasmani dan ruhani. Perilaku manusia merupakan produk tarik menarik antara energi spiritual dan material atau ruhaniah dan jasmaniah. Dorongan spiritual senantiasa membuat kemungkinan membawa dimensi material kepada dimensi spiritualnya. Yakni dengan cara menginternalisasi sifat-sifat-Nya, menjalani kehidupan dengan petunjukNya dan meneladani rosul-Nya. Tujuannya adalah mencapai ridho-Nya. ${ }^{15}$

Kepemimpinan spiritual merupakan kepemimpinan yang membawa dimensi keduniawian kepada dimensi spiritual. Tuhan merupakan pemimpin sejati yang mengilhami, mencerahkan, membersihkan hati nurani dan memenangkan jiwa hambaNya dengan cara yang sangat

15 Tobroni, The Spiritual Leadership (Pengefektifan Organisasi Noble Industry melalui Prinsip-prinsip Spiritual), 5. 
bijaksana melalui pendekatan etis dan keteladanan. Hendricks, Ludeman dan Tjahjono mengatakan kepemimpinan spiritual adalah kepemimpinan yang mampu mengilhami, membangkitkan, mempengaruhi, dan menggerakan melalui keteladanan, pelayanan, kasih sayang dan implementasi nilai dan sifat-sifat ketuhanan lainnya dalam tujuan, proses, budaya dan perilaku kepemimpinan.

Dalam perspektif sejarah Islam, kepemimpinan spiritual dapat merujuk kepada pola kepemimpinan yang diterapkan olehNabiMuhammadSAW.NabiMuhammad SAW menerapkan kepemimpinan paling ideal dan sukses dalam sejarah peradaban umat manusia yaitu sifatnya yang utama diantaranya siddiq, amanah, tabligh dan fathanah mampu mempengaruhi orang lain dengan cara mengilhami tanpa mengindoktrinasi, menyadarkan tanpa menyakiti, membangkitkan tanpa memaksa, dan mengajak tanpa memerintah.

Banyak teori yang muncul mengenai kepemimpinan spiritual. Menurut Tobroni kepemimpinan spiritual merupakan kepemimpinan sejati atau kepemimpinan yang sesungguhnya. Ia memimpin dengan hati berdasarkan pada etika religius. Ia mampu membentuk karakter, integritas dan keteladanan yang luar biasa. Model kepemimpinannya tidak dipengaruhi oleh faktor eksternal semata, melainkan lebih banyak dibimbing oleh faktor internal yaitu hati nuraninya. Adapun karakteristik kepemimpinan spiritual yang berbasis pada etika religious antara lain $^{16}$ :

\section{Kejujuran sejati}

Rahasia sukses pemimpin besar dalam memimpin organisasinya yaitu memegang teguh kejujuran. Kejujuran senantiasa membawa pada keberhasilan walaupun terkadang dalam prosesnya mengalami kepahitan. Orang jujur adalah orang yang

${ }^{16}$ Tobroni, 20. memiliki integritas. Dengan integritas seseorang akan dapat dipercaya.

2. Fairness

Pemimpin spiritual akan berlaku adil dalam setiap tindakannya. Baik adil terhadap diri sendiri, keluarga dan orang lain. Bagi pemimpin spiritual berlaku adil tidak sekedar kewajiban moral religious, melainkan sebuah proses dan strategi dalam menjalankan kepemimpinannya.

3. Semangat amal shaleh

Pemimpin spiritual dalam menajalankan organisasinya akan memberikan kontribusi, amal shaleh bagi lembaga dan orang yang dipimpinnya. Ia rela berkorban demi kepentingan organisasi dan orang didalamnya.

4. Membenci formalitas dan organized religion

Pemimpin spiritual akan lebih mengedepankan tindakan yang genuine dan substantif. Pemimpin spiritual akan merasa puas ketika mampu memberdayakan, memampukan, mencerahkan dan membebaskan orang dan lembaga yang dipimpinnya

5. Sedikit bicara banyak kerja dan santai

Pemimpin spiritual adalah pemimpin yang sedikitbicara banyak bekerja. Pemimpin spiritual akan merasa takut ketika bicara banyak dan tidak berguna. Karena banyak bicara cenderung akan banyak masalah yang ditimbulkan. Dengan prinsip tersebut ia akan menghargai waktu dan sumber daya sehingga dapat belerja secara efektif.

6. Membangkitkan yang terbaik bagi diri sendiri dan orang lain

Pemimpin spiritual akan berupaya mengenali jati dirinya dan orang lain. Dengan mengenali jati diri ia akan dapat membangkitkan segala potensinya dan bersikap secara arif dalam segala situasi.

7. Keterbukaan menerima perubahan

Pemimpin spiritual senang dengan adanya perubahan karena sadar perannya 
sebagai pemimpin memang untuk membawa perubahan. Pemimpin spiritual berkeyakinan bahwa lembaga yang dipimpinnya merupakan sarana untuk berdedikasi kehadirat Allah SWT, sehingga ia rela berkorban demi kepentingan lembaga dan orang didalamnya.

\section{Pemimpin yang dicintai}

Bagi pemimpin spiritual cinta kasih merupakan roh organisasi. Cinta kasih dalam hal ini adalah cinta kasih yang memberdayakan, bukan semata-mata bersifat perorangan melainkan cinta kasih structural yaitu cinta terhadap ribuan orang yang dipimpinnya.

2. Visioner tetapi focus pada persoalan didepan mata

Pemimpin spiritual memiliki visi jauh kedepan tanpa melupakan keadaan organisasi yang ada didepan mata. Ia mampu membangkitkan dan mengarahkan anggotanya untuk bersama-sama mencapai visinya.

\section{Doing the right thing}

Kepemimpinan spiritual adalah kepemimpinan etis. Pemimpin spiritual tidak hanya sekedar mempengaruhi, menggerakan dan mencapai tujuan melainkan untuk mencapai tujuan-tujuan yang etis (benar).

4. Disiplin tetapi fleksibel dan tetap cerdas dan penuh gairah

Kedisiplinan pemimpin spiritual tidak didasarkan pada bekerja otoritarian, melainkan didasarkan pada komitmen dan kesadaran spiritual. Selain itu, pemimpin spiritual mampu mendisiplinkan diri dari tindakan yang kurang bermanfaaat. Prinsip tersebut menjadikannya orang yang teguh, cerdas dan bergairah.

\section{Kerendahan hati}

Pemimpin spiritual menyadari sepenuhnya bahwa kedudukan, prestasi, pujian dan kehormatan bukan karena dia dan untuk dia, melainkan karena Allah dan untuk Allah SWT semata. Ia hanya sebagai perantara untuk menyalurkan karunia kepemimpinannya.
Selain Tobroni, Percy, 2003 dalam bukunya Going Deep. Exploring Spirituality in life and leadership, kepemimpinan spiritual yaitu kepemimpinan yang dapat dijalankan dengan formula 30/30/20/20, maksudnya yaitu seorang Spiritual Leadership menghabiskan 30\% waktunya untuk berfikir, dia mempercayai dan mengembangkan kemampuan otaknya, bisa dikatakan dia seorang yang berpikir realistis. $30 \%$ berikutnya adalah digunakan untuk komunikasi. baik komunikasi yang dilakukan didalam maupun luar organisasi, berusaha komunikasi berjalan efektif. 20\% adalah untuk melakukan pengawasan dan pembinaan. Dan yang terakhir 20\% digunakan untuk operasional, dapat dikatakan dia menguasai tugas secara teknis. Atau sangat menguasai kondisi organisasi.

Sedangkan tokoh lain yaitu Fry Eori kepemimpinan spiritual adalah teori kepemimpinan yang dirancang untuk menciptakan motivasi intrinsik. Kepemimpinan spiritual terdiri dari nilai, sikap dan perilaku untuk memotivasi diri sendiri dan orang lain untuk memiliki rasa spiritual dalam hidupnya melalui keterpanggilan dan keanggotaan, memiliki makna dalam hidup mereka, merasa dimengerti dan dihargai. Mereka merasa mengalami kehidupan yang berarti. Teori Kepemimpinan Spiritual dikembangkan dalam model motivasi intrinsik yang mengembangkan visi, harapan/keyakinan dan cinta altruistik. Tujuan kepemimpianan Spiritual untuk memenuhi kebutuhan mendasar dari pemimpin dan pengikut untuk kelangsungan hidup spiritual melalui keterpanggilan dan keanggotaan. Hal ini memerlukan : pertama ciptakan visi dimana pemimpin dan pengikut mengalami rasa keterpanggilan, kedua membangun budaya sosial, berdasarkan nilai cinta altruistik dimana pemimpin dan pengikut memiliki rasa keanggotaan, merasa dimengerti 
dan dihargai. ${ }^{17}$

\section{Guru Sebagai Pembentuk Karakter}

Dalam menjalankan fungsinya, guru memiliki berbagai macam tugas. Selain yang telah dijelaskan sebelumnya yaitu guru sebagai pemimpin, ternyata guru memiliki tugas yang tidak kalah mulia yaitu sebagai pembentuk karakter. ${ }^{18}$ Disadari atau tidak, perilaku dan sikap guru sehari-hari merupakan praksis moral yang menyampaikan nilai terhadap peserta didik.

Pendidikan karakter sedang hangathangatnya diperbincangkan. Namun, tetap saja hasilnya bias. ${ }^{19}$ Karena pada dasarnya pendidikan karakter sudah lama diterapkan di Indonesia, yaitu dengan memasukannya kedalam kurikulum untuk dapat diajarkan dalam sebuah mata pelajaran khusus dengan sebutan pendidikan nilai, pendidikan budi pekerti, pendidikan moral pancasila hingga sekarang pendidikan karakter tidak hanya menjadi sebuah nama mata pelajaran, melainkan nilai-nilai karakter sudah dimasukkan kedalam masing-masing mata pelajaran seperti yang tercantum dalam kurikulum 2013. Namun hal tersebut tidak menjamin bahwa sekolah memberikan perhatian pada pendidikan karakter tanpa eksplisitasi pembelajaran nilai.

Konsep pendidikan karakter tersebut hanya representasi dari pemikiran fragmentaris yang memisahkan antara pendidikan karakter sebagai diskursus dan praksis.Memisahkan dua gagasan tersebut mengakibatkan pendidikan karakter tereduksi maknanya yaitu hanya sekedar

17 Ratna Pujiastuti, "Karakteristik Spiritual Leadership Perangkat Desa Di Kabupaten Banyumas (Berdasar Teori Spiritual Leadership Fry)" (Seminar Nasional dan Call For Paper (Sancall 214), Purwokerto, 2014).

18 Doni Koesuma A, Pendidikan Karakter: Di Zaman Keblinger (Jakarta: Grasindo, 2010), 134.

${ }_{19}$ Aninditya, "Seminar Proposal Jurusan PGMI Program Magister" (Pada Saat Perkuliahan, UIN Sunan Kalijaga Yogyakarta, t.t.). diajarkan sebagai teori bukan penanaman nilai. Oleh karena itu, guru hadir sebagai pembentuk karakter peserta didik dengan mengintegrasikan diskursus dan praksis, sehingga guru tidak sekedar mengajarkan nilai melainkan juga menanamkan nilai melalui keteladanan. ${ }^{20}$ Tugas guru sebagai pembentuk karakter tentunya tidak terjadi begitu saja, namun guru perlu melakukan usaha untuk menemukan dan mengembangkan sikap dasar yang ada dalam dirinya sehingga layak dikatakan sebagai pembentuk karakter. Adapun sikap dasar yang perlu dikembangkan guru tersebut antara lain ${ }^{21}$ :

1. Anti adultisme

Adultisme merupakan sebuah keyakinan yang percaya bahwa peserta didik merupakan individu yang belum dewasa. Sehingga layak dianggap sebagai anak-anak dan pendapat-pendapatnya tidak menjadi pertimbangan. Guru sebagai pembentuk karakter perlu membuang jauh-jauh sifat tersebut. Sudah sepatutnya guru menjalin keakraban dengan peserta didik dengan mendengar keluh kesah yang dihadapi peserta didik serta menghargai pendapatpendapatnya.

2. Mengejar kesempurnaan

Sebagai pembentuk karakter guru tidak akan pernah merasa puas dengan apa yang telah diraih. Guru pembentuk karakter akan selalu berusaha mengembangkan dirinya untuk menjadi lebih baik. Tidak hanya itu, guru pembentuk karakter juga memiliki keyakinan kepada peserta didiknya bahwa mereka juga dapat tumbuh dan berubah menjadi lebih baik, sehingga duaduanya akan tumbuh menjadi indiidu yang berkarakter.

3. Penghayatan nilai secara otentik

Guru pembentuk karakter mampu menghayati nilai-nilai moral

${ }^{20}$ A, Pendidikan Karakter: Di Zaman Keblinger, 135.

${ }^{21} \mathrm{~A}, 154$. 
dan kemanusiaan yang diyakininya dan melaksanakannya didalam hidup. Nilai-nilai tersebut yang yang membuat Ia semangat, rela berkorban dalam mendidik peserta didik. Ia terlebih dahulu memotivasi dirinya menjadi lebih baik sebelum ia meminta peserta didik untuk melakukannya.

4. Praksis tanggung jawab pribadi

Guru pembentuk karakter mesti mengajak peserta didik untuk menghayati tanggung jawabnya secara pribadi. Guru mesti memliki kepercayaan bahwa peserta didik merupakan individu yang dapat menentukan pilihannya. Karena mereka juga mampu berfikir, mempertimbangkan, dan merefleksikan pengalaman.

\section{Ekselensi sebagai pembelajar}

Guru pembentuk karakter tidak akan pernah berhenti belajar. Ia akan terus mengembangkan dirinya seiring dengan kemajuan IPTEK. Ia selalu mengupgrade pengetahuannya dengan terus belajar. Selain mengembangkan dirinya guru juga mengembangkan kemampuan akademis peserta didik, dengan melakukan pembaruan-pembaruan dalam mengajar, mengorganisir kelas, merefleksikan dan mengevaluasi secara terus enerus.

6. Pengembangan tenggung jawab social

Guru pembentuk karakter akan melibatkan seluruh peserta didik dalam segala aktivitas tanpa ada yang merasa dikucilkan. Guru akan membimbing peserta didiknya untuk terus tumbuh bersama-sama dalam proses belajarnya. Guru bersama peserta didik selalu berusaha menciptakan suasana pembelajaran yang menyenangkan guna kemajuan bersama.

\section{Kepemimpinan Spiritual Guru SD dalam Pembentukan Karakter Peserta Didik}

Kepemimpinan spiritual yang telah penulis paparkan dari beberapa tokoh dapat ditarikkesimpulanbahwapemimpinspiritual yaitu sesorang pemimpin yang memimpin organisasinya dengan mengedepankan faktor intrinsik, yaitu menggunakan hati dalam setiap tindakannya. Artinya, ia selalu mengikuti kata hati dengan selalu mengembalikannya kepada Allah SWT untuk mencari ridha-Nya.

Pemimpin spiritual mampu memberikan teladan yang luar biasa kepada anggotanya dengan mengimplementasikan sifat-sifatketuhanan.Iamenggunakan prinsip cinta dan kasih sayang dalam memimpin organisasinya. Ia bekerja untuk kemajuan organisasi dan anggotanya tanpa memikirkan sama sekali kepentingan pribadinya. Ia rela berkorban walaupun dirinya bisa saja hancur. Kedekatannya dengan Allah SWT membuat dirinya selalu tenang, nyaman dan bahagia dalam memimpin organisasi walaupun dalam menghadapi masalah genting sekalipun ia tidak pernah merasa panik dan gugup karena ia memegang prinsip bahwa semuanya berasal dari Allah dan akan kembali pada Allah.

Kaitannya dengan guru Sekolah Dasar yaitu bahwa guru merupakan pemimpin bagi peserta didik dikelasnya, sehingga jika guru menginginkan kesuksesan dalam memimpin peserta didiknya maka guru perlu menerapkan model kepemimpinan spiritual. Akan tetapi kebanyakan guru kurang menyadari perannya sebagai pemimpin. Guru hanya menyadari bahwa dirinya hanyalah sang penyampai informasi dalam hal ini adalah penyampai materi saja. Sehingga setelah selesai menyampaikan materi guru merasa bahwa tugasnya telah selesai. Sehingga dalam hal ini terlebih dahulu guru perlu diberi kesadaran bahwa ia memiliki tugas yang begitu mulia selain hanya sebagai penyampai materi yaitu sebagai pemimpin di kelas.

Setelah guru memahami perannya sebagai pemimpin di kelas, lalu ia perlu menerapkan model kepemimpinan yang dijadikan pedoman dalam memimpin. Model 
kepemimpinan paling ideal seperti yang telah dijelaskan sebelumnya yaitu model kepemimpinan spiritual (spiritual leadership). Dengan menerapkan model kepemimpinan spiritual guru akan meraih kesuksesan dalam memimpin peserta didiknya.

Kepemimpinan spiritual erat sekali kaitannya dengan pembentukan karakter. Hal tersebut senada dengan peran guru yang lain yaitu guru sebagai pembentuk karakter. Sehingga, jika guru mencita-citakan peserta didiknya menjadi pribadi yang berkarakter guru sangat perlu menerapkan model kepemimpinan spiritual (spiritual leadership).

Guru dengan menerapkan kepemimpinan spiritual akan melibatkan hati dalam tindakannya dan tidak akan terlepas dari bimbingan sang pencipta. Guru yang dengan spiritualnya akan berhatihati dalam memimpin peserta didiknya. Ia tidak ceroboh dalam tindakannya, Ia akan selalu mengembalikan segala tindakannya kedalam hatinya benar ataukah keliru. Ia selalu meminta bimbingan dari Allah SWT.

Adapun dari karakteristik kepemimpinan spiritual yang dijelaskan oleh beberapa tokoh, penulis dapat menyimpulkan bahwa karakteristik guru yang menerapkan model kepemimpinan spiritual dalam memimpin peserta didik setidaknya memiliki kriteria yaitu taqwa, tawakal dan tawadhu (3T) :

1. Taqwa

Taqwa secara bahasa yaitu sesuatu yang digunakan seseorang untuk menjaga dirinya. Sedangkan dalam pengertian istilah taqwa yatiu dasar agama yang mengangkat kepada tingkatan yakin. Ia adalah bekal hati danjiwa, dengannyahatidanjiwa akanterjaga dan berhati-hati meraih keselamatan. ${ }^{22}$

Sedangkan pengertian taqwa menurut Alquran yaitu sebagai berikut:

22 Muhammad Shalih Al-Munajjid, Jagalah Hati Raih Ketenangan (Jakarta: Cakrawala Publishing, 2006), 354. a. Takut dan khawatir, firman Allah Q.S. Albaqarah (2) : 281, “ dan takutlah pada suatu hari dimana kalian dikembalikan kepada allah pada saat itu"

b. Ketaatan dan ibadah, firman Allah Q.S. Ali-imran (3) : 102, "wahai orang-orang yang beriman bertaqwalah kepada allah dengan sebenar-benarnya taqwa"

c. Pembersihan diri dari dosa, firman Allah Q.S. An-nur (24): 52 " dan barang siapa taat kepada allah dan rasul-Nya dan takut kepada allah dan bertaqwa kepada-Nya, maka mereka adalah orang-orang yang beruntung"

Dari pengertian taqwa tersebut dapat disimpulkan bahwa guru yang bertaqwa akan takut kepada Allah, karena dalam segala tindakannya ia menyadari selalu diawasi oleh Allah termasuk ketika ia menjalankan perannya sebagai pemimpin bagi peserta didiknya.Sehingga ia berhati-hati dalam bertindak dan mengambil keputusan, ia akan selalu meminta bimbingan dari Allah sehingga ia tidak terjebak dalam kesesatan. Ia tidak hanya menjaga dirinya namun akan menjaga peserta didik untuk mendekat kepada Allah agar sama-sama meraih keselamatan.

2. Tawakal

Tawakal merupakan tingkatan akhlaq yang tinggi dan mempunyai pengaruh yang luar biasa bagi pelakunya. Tawakal adalah hasil dari keimanan yang terbesar, amalan dan ibadah paling utama yang dapat mendekatkan diri kepada Allah SWT. Segala cita-cita dan harapan tidak akan tercapai kecuali dengan tawakal dan pertolongan dari Allah. ${ }^{23}$

Tawakal berkaitan erat dengan segala urusan, karena kebutuhan manusia begitu banyak maka tawakal merupakan solusi dalam menyelesaikan segala permasalahan hidup dan kehidupan, termasuk masalah yang dihadapi guru.

$$
\text { Guru sebagai pemimpin akan }
$$

.Al-Munajjid, 35

\section{$r$}


menghadapi berbagai permasalahan dalam menjalankan kepemimpinannya. Termasuk permasalahan dengan yang dipimpinnya yaitu peserta didik. Guru yang dekat dengan allah akan bertawakal dalam menghadapi permasalahan yang terjadi. Ia tidak akan bersedih dan berputus asa, ia meminta pertolongan allah dalam menghadapi permasalahannya karena ia menyadari bahwa semua permasalahan berasal dari Allah dan hanya Allah yang memiliki solusi dari permasalahan tersebut. Sehingga ia akan meminta petunjuk dalam menyelesaikan permasalahannya. Dengan begitu ia akan meraih kesuksesan dalam menjalankan kepemimpinannya karena langsug dibimbing oleh Allah.

\section{Tawadhu}

Tawadhu merupakan sikap rendah hati, tidak sombong walaupun meraih kesuksesan. Tawadhu artinya menyadari sepenuhnya bahwa ia tidak akan dapat melakukan apapun tanpa bimbingan Allah SWT. Semuanya karena Allah dan akan kembali pada Allah.

Guru yang tawadhu akan sepenuhnya menyadari bahwa dirinya sama sekali tidak memiliki kemampuan untuk memimpin, ia menyadari bahwa itu merupakan karunia Allah SWT yang dititipkan kepadanya. Ia hanyalah perantara dalam memimpin peserta didik. Guru yang memiliki sifat tawadhu akan meraih kesuksesan dalam menjalankan kepemimpinannya. Karena ia akan selalu berhati-hati dalam tindakannya. Lalai sedikit akan membawa kegagalan. Ia selalu bergantung kepada Allah SWT.

Dari karakteristik dengan kepemimpinan spiritual tersebut guru akan melahirkan peserta didik yang luar biasa yang kelak akan menjadi pemimpin selanjutnya yaitu pemimpin yang berkarakter. Seorang guru yang memimpin dengan model kepemimpinan spiritual akan menghasilkan peserta didik yang unggul, komitmen dan berkarakter. Perlu diketahui bahwa pada dasarnya, nilai suatu agama ada pada karakter seseorang. Seseorang yang berkarakter baik Ia tidak lepas dari pemahaman agama yang dimilikinya begitu juga sebaliknya. Sehingga jika ditilik karakter yang baik yang dimiliki seseorang sebagai hasil dari kepemimpinan spiritual yaitu karakter yang segala tindakannya adalah suatu kebaikan. Sehingga peserta didik yang berkarakter selalu melakukan apa-apa yang menurut mereka benar bahkan ketika menghadapi tekanan atau permasalahan.

\section{Kesimpulan}

Berdasarkan hasil penelitian dapat disimpulkan bahwa kepemimpinan spiritual yaitu model atau cara memimpin seseorang dengan menggunakan hati dan perasaan yang mana memiliki karakteristik yaitu taqwa, tawakal dan tawadhu. Sehingga dengan memimpin menggunakan spiritual diharapkan akan menghasilkan peserta didik yang berkarakter.

\section{Daftar Pustaka}

A, Doni Koesoema. Pendidikan Karakter (Utuh dan Menyeluruh). Yogyakarta: Kanisius, 2012.

A, Doni Koesuma. Pendidikan Karakter: Di Zaman Keblinger. Jakarta: Grasindo, 2010.

Afifah, Nurul. "Problematika Pendidikan di Indonesia (Telaah Aspek Pembelajaran)." Elementary: Jurnal Ilmiah Pendidikan Dasar 1, no. 1 (2015).

Al-Munajjid, Muhammad Shalih. Jagalah Hati Raih Ketenangan. Jakarta: Cakrawala Publishing, 2006.

Aninditya. "Seminar Proposal Jurusan PGMI Program Magister." dipresentasikan pada Pada Saat Perkuliahan, UIN Sunan Kalijaga Yogyakarta, t.t. 
Asmaningrum, Nurfika, Budi Anna Keliat, dan Sutanto Priyo Hastono. "Pengaruh Penerapan Spiritual Leadership Terhadap Komitmen Perawat Pada Organisasi Di Rumah Sakit Islam Surabaya." Jurnal Keperawatan Soedirman 6, no. 1 (Maret 2011): 11.

Bakar, Norashikin Abu, Ramli Basri, dan Foo Say Fooi. "Hubungan Kepimpinan Guru dengan Pencapaian Akademik Pelajar." International Journal Of Education And Training 1, no. 11 (2015).

Djamarah, Syaiful Bahri. Guru dan Anak Didik dalam Interaksi Edukatif (Suatu Pendekatan Teoretis Psikologis). Jakarta: Rineka Cipta, 2005.

Kurniawan, Syamsul. Pendidikan Karakter

(Konsepsi \& Implementasinya Secara TerpadudiLingkungan Keluarga, Sekolah, Perguruan Tinggi dan Masyarakat). Yogyakarta: Ar-Ruzz Media, 2016.

Kusuma, Ardha H. "Pengaruh Kepemimpinan Guru dan Disiplin Belajar terhadap Prestasi Belajar Mata Pelajaran Ekonomi Siswa Kelas XI IPS SMA PGRI 1 Pati Tahun Ajaran 2012/2013." dipresentasikan pada Skripsi, Universitas Negeri Semarang, 2013.

Maulana, Rahmad. “Hubungan Kompetensi Sosial dengan Kinerja Guru SD Islam Bunga Bangsa Samarinda Ditinjau dari Tipe Kepribadian." Jurnal Psikologi 2, no. 2 (2014).

Moleong, Lexy J. Metode Penelitian Kualitatif. Bandung: Remaja Rosdakarya, 1990.

Pangaribuan, Darwin. "Peranan Seorang Guru Sebagai Pemimpin." dipresentasikan pada Seminar Pendidikan Balai Keratun, Bandar Lampung, 8 April 2010.

Pujiastuti, Ratna. “Karakteristik Spiritual
Leadership Perangkat Desa Di Kabupaten Banyumas (Berdasar Teori Spiritual Leadership Fry)." dipresentasikan pada Seminar Nasional dan Call For Paper (Sancall 214), Purwokerto, 2014.

Tobroni. The Spiritual Leadership (Pengefektifan Organisasi Noble Industry melalui Prinsip-prinsip Spiritual). Cet 2 . Malang: UMM Press, 2010.

Wardani, Imas S. “Guru sebagai Pemimpin Pendidikan." Jurnal Buana Pendidikan 10, no. 18 (2014). 
74| Hlementitiry Vol. 4 Edisi Januari-Juni 2018

halaman ini bukan sengaja untuk dikosongkan 